\title{
MENGENAL PENYAKIT MENUJU SEHAT
}

Oleh: Sumarjo

Dosen Jurusan Pendidikan Kesehatan dan Rekreasi FIK UNY

\section{Abstrak}

Kesehatan merupakan kata yang sangat sulit didefinisikan, tetapi yang lebih penting adalah anda mengetahui dan telah melaksanakan aktivitas menuju hidup yang sehat. Penentu kualitas hidup yang sehat ada empat komponen: gaya hidup, lingkungan, perawatan kesehatan, dan keturunan. Keempat komponen tersebut, tiga dapat dikelola atau diubah menuju yang lebih baik, tetapi khusus faktor keturunan tidak dapat dikelola atau diubah.

Ada lima langkah untuk mencegah supaya tidak terkena penyakit. Pertama promosi kesehatan (Health Promotion), kedua memberikan perlindungan khusus (Specific Protection), ketiga mengenal penyakit dan mengobati secara tepat (Early Diagnosis and Prompt Treatment), keempat membatasi cacat (Disability Limitation), dan kelima merehabilitasi (Rehabilitation). Hubungan antara perkembangan penyakit dan langkah pencegahan adalah sejajar.

Kata Kunci :Sehat, pencegahan penyakit. 
Kesehatan merupakan modal bagi seseorang untuk melakukan aktifitas fisik sehari-hari. Oleh karena itu setiap orang selalu'berusaha untuk mempertahankan dan ataupun meningkatkan kesehatannya dengan berbagai cara. Tergantung dari latar belakang kehidupan orang perorang dan atau masyarakat secara keseluruhan seperti misalnya sosial, budaya, kepercayaan, adat istiadat, ekonomi dan tingkat pendidikan. Sehingga pada saat ini banyak cara melakukannya atau pengobatan modern, tradisional dan alternatif. Ketiga cara itu selalu digali kebenarannya secara ilmiah, agar tindakan yang dilakukan tidak menimbulkan masalah baru yang justru bertentangan dengan manfaat yang ingin dicapai.

Peningkatan status kesehatan seolah-olah sangat tergantung dengan sarana/prasarana dan pelayanan sehingga berbagai pihak selalu menyediakan atau mengadakan fasilitas. Padahal penentu utama untuk mencapai status kesehatan tersebut 53 persen tergantung dari gaya hidup atau perilaku individu atau masyarakat jika cakupannya status kesehatan masyarakat. Banyak lembaga pemerintah dan swasta menyelenggarakan pendidikan yang menghasilkan lulusan untuk memberikan bimbingan dan

MEDIKORA Vol. IV, No 1, April 2008: 66-82 
penyuluhan (promosi kesehatan) bertujuan mengubah perilaku seseorang atau masyarakat.

Jika derajat kesehatan seseorang hingga sekelompok masyarakat telah tercapai atau meningkat, bagaimanakah cara mempertahankannya agar selalu ajeg atau konstan. Usaha dan daya dilakukan untuk tetap melaksanakan perilaku hidup sehat, kegiatan inilah yang dinamakan motivasi atau kegairahan yang positif.

\section{Sehat Menyeluruh}

Beberapa dasawarsa yang lalu, Badan Kesehatan Dunia (World Health Organization/WHO) mendefinisikan sebagai status kenyamanan menyeluruh dari jasmani, mental dan sosial, dan bukan hanya tidak ada penyakit atau kecacatan. Jika tubuh sehat maka kegiatan sehari-hari dapat dilakukan tanpa kelelahan yang berarti, atau dapat lebih produktif, dituangkan dalam missinya yaitu Health for All untuk tahun 2000. Negara Indonesia dengan missi tersebut tidak mampu mewujudkan karena terganggu situasi ekonomi, sehingga targetnya diundur untuk tahun 2010.

Kesehatan sebagai salah satu unsur kesejahteraan umum harus diwujudkan sesuai dengan cita-cita bangsa Indonesia sebagaimana dimaksudkan dalam pembukaan 
UUD 1945 melalui pembangunan nasional yang berkesinambungan berdasarkan Pancasila dan UUD 1945.

Pembahngunan kesehatan diarahkan untuk mempertinggi derajat kesehatan yang besar artinya bagi pembangunan dan pembinaan sumber daya manusia Indonesia dan sebagai modal bagi pelaksanaan pembangunan nasional yang pada hakikatnya adalah pembangunan manusia Indonesia seutuhnya dan pembangunan seluruh masyarakat Indonesia.

Penyelenggaraan pembangunan kesehatan meliputi upaya kesehatan dan sumber dayanya harus dilakukan secara terpadu dan berkesinambungan guna mencapai hasil yang optimal. Upaya kesehatan yang semula dititikberatkan pada upaya penyembuhan penderita secara berangsur-angsur berkembang ke arah keterpaduan upaya kesehatan yang menyeluruh. Oleh karena itu, pembangunan kesehatan yang menyangkut upaya peningkatan kesehatan (promotif), pencegahan penyakit (preventif), penyembuhan penyakit (kuratif), dan pemulihan kesehatan (rehabilitatif) harus dilaksanakan secara menyeluruh, terpadu dan berkesinambungan dan dilaksanakan bersama antara pemerintah dan masyarakat.

MEDIKORA Vol. IV, No 1, April 2008: 66-82 
Peran aktif masyarakat termasuk swasta perlu diarahkan, dibina dan dikembangkan sehingga dapat melakukan fungsi dan tanggung jawab sosialnya sebagai mitra pemerintah. Peran pemerintah lebih dititikberatkan pada pembinaan pengaturan, dan pengawasan untuk terciptanya pemerataan pelayanan kesehatan dan tercapainya kondisi yang serasi dan seimbang antara upaya kesehatan yang dilaksanakan oleh pemerintah dan masyarakat termasuk swasta. Kewajiban untuk melakukan pemerataan dan peningkatan pelayanan kesehatan bagi seluruh lapisan masyarakat, tetap menjadi tanggung jawab pemerintah.

Keberhasilan pembangunan disegala bidang dan kemajuan ilmu pengetahuan dan teknologi telah meningkatkan taraf kesejahteraan masyarakat dan kesadaran akan hidup sehat. Hal ini mempengaruhi meningkatnya kebutuhan pelayanan dan pemerataan yang mencakup tenaga, sarana dan prasarana baik jumlah maupun mutu.

Ketentuan umum dalam undang-undang kesehatan ada beberapa istilah untuk pendidikan kesehatan (Depkes, 1992). Kesehatan adalah keadaan sejahtera dari badan, jiwa dan sosial yang memungkinkan setiap orang hidup produktif secara sosial dan ekonomis. 
Upaya kesehatan adalah setiap kegiatan untuk memelihara dan meningkatkan kesehatan yang dilakukan oleh pemerintah dan atau masyarakat untuk meningkatkan derajat kesehatan.

Tenaga kesehatan adalah setiap orang yang mengabdikan diri dalam bidang kesehatan serta memiliki pengetahuan dan atau keterampilan melalui pendidikan di bidang kesehatan yang untuk jenis tertentu memerlukan kewenangan untuk melakukan upaya kesehatan. Sarana kesehatan adalah tempat yang digunakan untuk menyelenggarakan upaya kesehatan baik yang disediakan oleh pemerintah maupun swasta.

Kesehatan matra adalah upaya kesehatan yang dilakukan untuk meningkatkan kemampuan fisik dan mental guna menyesuaikan diri terhadap lingkungan yang berubah secara bermakna baik lingkungan darat, udara, angkasa, maupun air.

Mewujudkan derajat kesehatan masyarakat adalah upaya untuk meningkatkan keadaan kesehatan yang lebih baik dari sebelumnya. Derajat kesehatan masyarakat yang optimal adalah tingkat kondisi kesehatan yang tinggi dan mungkin dapat dicapai pada suatu saat sesuai dengan kondisi dan situasi serta kemampuan yang nyata dari setiap

MEDIKORA Vol. IV, No 1, April 2008: 66-82 
orang atau masyarakat dan harus selalu diusahakan peningkatannya secara terus-menerus.

Merencanakan pendidikan kesehatan yang dikaitkan dengan olah raga kemasyarakatan bermotif kesegaran jasmani dan kesehatan seperti gerakan hidup sehat (gesat) yang berada di Bandung sehingga materi pendidikan disesuaikan dengan kebutuhan masyarakat. (Depkes, 2005)

Badan Kesehatan Dunia

(World

Health Organization/WHO) dalam memperingati hari kesehatan mencanangkan tema "Move for Health" yang merupakan kegiatan yang diadakan dengan komitmen bersama di sekolah untuk aktivitas fisik, yang dapat menurunkan penyakit degeneratif, untuk meningkatkan kesehatan semua yang merupakan kebutuhan dasar yang perlu mendapat perhatian (Depkes 2000).

\section{Klasifikasi Sehat}

Sehat Jasmani adalah dimensi sehat yang paling nyata dan mempunyai perhatian pada fungsi mekanistek tubuh baik secara anatomis maupun fisiologis.

Sehat Mental adalah kemampuan berpikir dengan jernih dan koheren. Istilah ini dibedakan dari kesehatan 
emosional dan sosial, meskipun ada hubungan yang dekat diantara ketiganya.

Sehat Emosional adalah kemempuan untuk mengenal rasa seperti takut, kenikmatan, kedukaan, kemarahan dan untuk mengekspresikan rasa-rasa itu secara tepat. Kesehatan emosional/afektif juga berarti penanganan strees, ketegangan jiwa. depresi dan kecemasan.

Sehat Sosial adalah kemampuan untuk membuat dan mempertahankan hubungan dengan orang lain.

Sehat Spiritual adalah berkaitan dengan kepercayaan, norma, tingkah laku dan kehidupan beragama.

Sehat Intelektual adalah kemampuan menghimpun dan menggunakan informasi yang dimiliki secara tepat.

Bagan keterkaitan antar unsur sehat

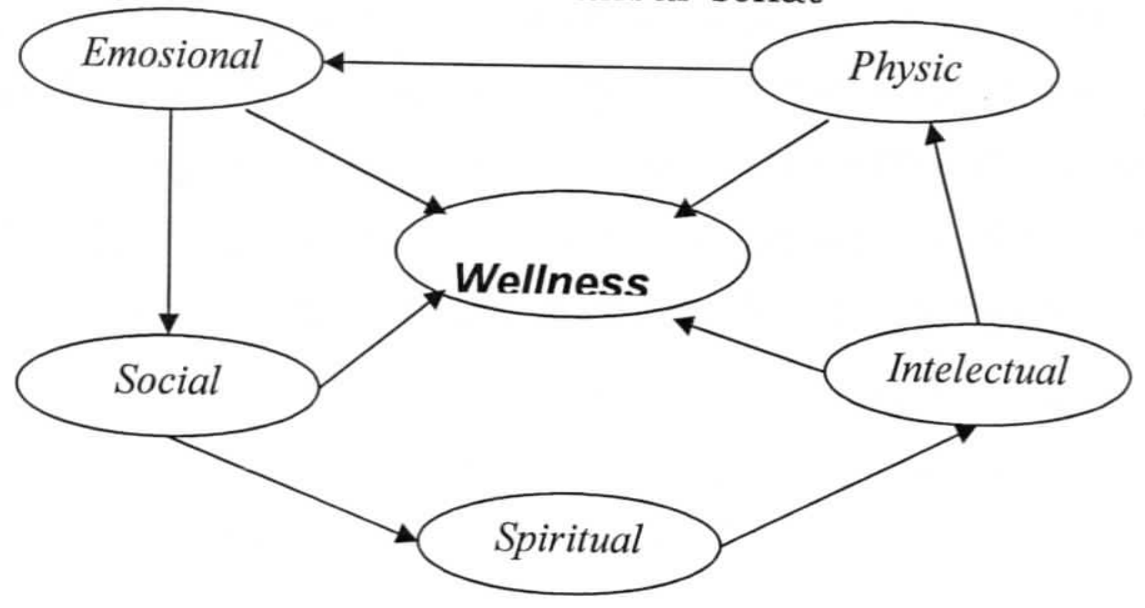

MEDIKORA Vol. IV, No 1, April 2008: 66-82 
Kita telah mempertimbangkan kesehatan pada tingkat individual, tetapi kesehatan seseorang tidak dapat lepas dari segala sesuatu yang melingkupi orang tersebut. Identifikasi beraneka aspek kesehatan merupakan latihan yang berguna dalam rangka meningkatkan kesadaran akan kompleksitas konsep sehat. Tetapi dalam kehidupan sehari-hari, adalah nyata bahwa membagi hidup orang ke dalam jasmani, mental dan seterusnya saling membawa kepada pembagian yang dibuat-buat. Semua aspek kesehatan adalah saling berkaitan dan bergantung, dan memiliki pandangan bahwa pandangan sehat yang menyeluruh mempunyai arti yang lebih besar bagi anda dan orang yang menjadi mitra anda dalam bekerja.

\section{Penentu Kualitas Hidup}

Ada empat komponen penentu kualitas hidup (life style), lingkungan (environment), perawatan kesehatan (health care) dan keturunan (human biology). Dari keempat tersebut tiga diantaranya dapat dilakukan perubahan atau dikelola, sedangkan yang satu keturunan tidak dapat diubah atau dikelola. 
Bagan penentu kualitas hidup

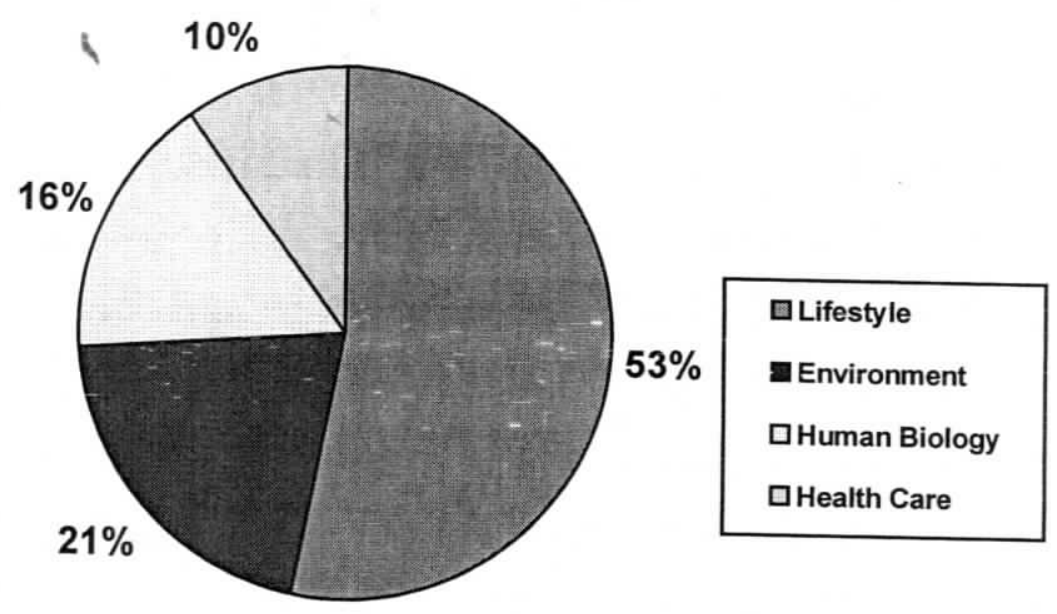

(Anspaugh DJ dkk, 1984)

Kegiatan yang dapat dilakukan untuk meningkatkan kualitas hidup tersebut adalah Gaya Hidup(lifestyle) : mempunyai peran paling tinggi terhadap kualitas hidup yaitu 53 \%. Kegiatannya : tidur 7-8 jam/malam, sarapan teratur, mempertahankan berat ideal, tidak merokok, olahraga teratur.

Lingkungan (environment); mempunyai peran $21 \%$ terhadap peningkatan kualitas hidup. Kegiatan ini berhubungan dengan keluarga, teman-teman dan masyarakat.Banyak kata bijak yang memberikan penjelasan tentang lingkungan ini, misalnya kalau mau jadi orang yang

MEDIKORA Vol. IV, No 1, April 2008: 66-82 
baik berkumpullah dengan orang yang baik pula. Ada juga peribahasa jawa "ojo cedak-cedak kebo gupak".

Perawatan kesehatan (health care) ini mempunyai peran $10 \%$ terhadap peningkatan kualitas hidup. Perawatan kesehatan ini tergantung dari sarana dan prasarana dan dokter yang ada. Paling dominan bukan sarana dan prasarananya, tetapi perilaku yang menuju perbaikan atau niat untuk berubah jadi lain walaupun disediakan sarana dan prasarana yang memadai tetapi tidak digunakan tidak akan meningkat derajat kesehatannya.

Keturunan (human biology) mempunyai peran $16 \%$ terhadap kualitas hidup, ini termasuk gen dari orang tua. Apakah orang tua mempunyai penyakit yang sifat penularannya melalui bawaan? Hal ini bisa dilacak melalui riwayat atau sejarah penyakitnya.

\section{Tips Motivasi Melakukan Olahraga}

Motivasi atau dorongan dalam beraktivitas mempunyai peran yang sangat kuat, terutama motivasi dari dalam diri sendiri (intrinsic).Untuk meningkatkan derajat kesehatan pribadi yang berdampak pada derajat kesehatan keluarga hingga masyarakat diperlukan aktifitas fisik yang tidak lain 
adalah kegitan berolahraga. Agar kegiatan olahraga tidak cepat menimbulkan kebosanan dapat dikuti tips dibawah ini:

a. Berolahragalah bersama teman, hal ini anda berdua paling tidak mempunyai tujuan dan derajat kesehatan yang sama.

b. Bergabunglah atau ikutilah suatu kelompok tim olahraga

c. Memperoleh manfaat dari dukungan teman dan keluarga

d. Pererat persatuan dengan cara beranjang sana dengan kelompok olahraga lain jika mungkin diadakan pertandingan persahabatan

e. Mengikuti kelas atau kelompok fitness

f. Buatlah catatan kemajuan pribadi dengan kartu catatan kegiatan

g. Buatlah jadwal kegiatan olahraga dan berusaha menepati.

h. Kuasai atau berlatihlah berbagai cabang olahraga sebagai variasi untuk kesehatan dan rekreasi.

i. Jangan terlalu maniak latihan atau olahraga yang justru menimbulkan sakit atau cedera

Dengan mengetahui berbagai cara agar tetap berolahraga, maka tidak ada kata lain kecuali mulai dari sekarang.

MEDI KORA Vol. IV, No 1, April 2008: 66-82 


\section{Pencegahan Penyakit}

Ada kegiatan mengkal/menolak penyakit yang sesuai dengan perkembangan penyakit. Prinsip pokok pencegahan hádala memutuskan rantai penularan bibit penyakit, lingkungan dengan manusia dan meninggikan status kesehatan manusianya. Tahap pencegahan yangsesuai dengan perkembangan penyakit ada lima tahap; pertama meninggikan mutu kesehatan, kedua memberikan perlindungan khusus, ketiga mengenal penyakit dan mengobati secara tepat, keempat membatasi cacat, dan relima merehabilitasi.

Tahap pertama meninggikan mutu kesehatan (Health Promotion), pada tahap ini manusia masih dalam kondisi sehat. Tujuan kegiatan ini adalah meningkatkan status kesehatannya atau paling tidak status kesehatannya tetap diatas rata-rata. Jenis kegiatan yang dapat dilakukan adalah olahraga secara teratur yang adikuat, pendidikan kesehatan yang sesuai kebutuhan, perbaikan gizi, pemeriksaan kesehatan secara teratur dan rekreasi yang sehat.

Tahap kedua memberikan perlindungan khusus (Specific Protection), tahap ini juga manusia masih dalam kondisi sehat. Tujuan dari tindakan ini adalah melindungi 
manusia dari kemungkinan terserang oleh bibit penyakit baik dengan terbentuknya pertahanan kekebalan dalam tubuh maupun terjadinya kontak langsung antara manusia dengan bibit penyakit yang didukung oleh kondisi lingkungan. Jenis kegiatan yang dapat dilakukan diantaranya melakukan imunisasi, memakai sarung tangan, masker saat bekerja dalam pabrik, memakai kacamata gelap dan helm saat berkendaraan roda dua, memakai kacamata dan tutup telinga saat berenang, dan menggunakan lampu yang sesuai saat membaca.

Tahap ketiga mengenal penyakit dan mengobati secara tepat (Early Diagnosis and Prompt Treatment), pada tahap ini manusia sudah sakit walaupun sifatnya masih sangat ringan, maka perlu dikenal gejala dan obat-obatan yang biasanya digunakan agar penyakitnya tidak berkembang pesat. Tujuannya adalah mengenal penyakit dan kemudian memberikan pengobatan, untuk menghilangkan rasa sakit saja yang belum membunuh bibit penyakinya. Khusus penyakit menular pada tahap ini sangat berarti, karena akan terhindar kemungkinan meluasnya penyakit di masyarakat. Tindakan yang dapat dilakukan adalah skrining terhadap suatu kelompok tertentu, pemeriksaan selektif dan kunjungan ke dokter yang sifatnya segera jika tidak

MEDIKORA Vol. IV, No 1, April 2008: 66-82 
mengetahui gejalanya, sehingga tidak akan terjadi keparahan penyakit.

Tahap keempat membatasi cacat (Disability Limitation), tahap ini penderitanya telah mengalami sakit dan bahkan kadang-kadang telah sakit berat. Tujuan dari tindakan ini adalah mencegah timbulnya cacat lebih lanjut, baik fisik ataupun cacat sosial maupun moral. Kegiatan yang dapat dilakukan pengobatan secara tepat dan tertib, tindakan kedokteran secara khusus misal amputasi yang disesuaikan dengan keadaan ekonomi dan sosial penderitanya.

Tahap kelima merehabilitasi (Rehabilitation), tindakan ini diberikan kepada penderita maupun keluarga dan masyarakat. Tujuan tindakan ini adalah mengembalikan penderita kepada kedaan semula baik fisik, sosial dan mental, atau paling tidak pada kedaan yang dipandang sesuai dan mampu melangsungkan fungsi kehidupannya. Kegiatan yang dapat dilakukan terapi fisik, bimbingan konseling dan latihan keterampilan untuk bekal hidup kembali di masyarakat. 


\section{KESIMPULAN}

Arti sehat bagi setiap orang berbeda-beda tergantung rasa dominan yang dialami,karena kesehatan itu holistik/menyeluruh fisik, intelektual, emosional, sosial dan spiritual dan saling berkaitan.

Untuk mencapainya ada berbagai langkah yang dapat dilakukan atau dikelola dengan cara mengubah gaya hidup, lingkungan dan perawatan kesehatan.

Jika dapat dibuat prosentase ketiga faktor itu maka berjumlah $84 \%$. Alangkah besarnya peran itu, yang sangat tergantung dari diri sendiri, mau berubah atau tidak. Menuju kualitas hidup yang lebih baik memerlukan motivasi/kegairahan yang optimal terutam motivasi intrinsic atau dari dalam diri pribadi, bukan semata -mata karena tidak adanya sarana prasarana.

\section{Daftar Pustaka}

Anspaugh, D.J., at 11 1994. Wellness; Concepts and Applications. Mosby. London.

Beaglehole,R.et all., 1993.Basic Epidemiology.WHO.Geneva Depkes,2005. Promosi dan Pencegahan Penyakit Tidak Menular.Http://www.promosi Kesehatan.com/program/promosi

MEDIKORA Vol. IV, No 1, April 2008: 66-82 
Depkes, 1992. Undang-Undang Republik Indonesia No 23. Tentang Kesehatan. Depkes. Jakarta.

Ewles L', dan Simnett I,1985.Promoting Health, A Practical Guide to Health Education. Anchor Press Ltd. New York. 